\title{
Enumeration of the new Hornworts from Bilaspur (Chhattisgarh), India.
}

Mery Aradhna Kerketta and A.K. Dixit*

Department of Botany, Guru Ghasidas Vishwavidyalaya, Koni, Bilaspur (Chhattisgarh), 495009, India.

Received: 9/29/2017; Accepted: 10/15/2017

\begin{abstract}
A preliminary survey of Bilaspur-Achanakmar Tiger Reserve (ATR) forest area shows that phylogenetically significant hornworts are quite dominant in the area. The smallest known group of bryophytes Anthoceros (Hornworts) is a terrestrial and cosmopolitan genus characterized by horn-shaped sporophyte. Present investigation deals with the morphotaxonomic account of three species of hornworts. Notothylas levieri Schiffn. Ex Steph., Anthoceros punctatus L., Sp. and Phaeoceros leavies (L.) Prosk., has been identified from different localities of Bilaspur- Achnakmar Tigar Reserve (ATR) and Achanakmar-Amarkantak Biosphere Reserve (AABR), Chhattisgarh. The comprehensive and consolidate account, has been provided along with identification key. All three were new reports to the Chhattisgarh Bryoflora.
\end{abstract}

Keywords: Hornworts, Bilaspur (AABR), Anthoceroteceae, Notothylas, Morphotaxonomy

\section{Introduction}

Bryophytes have a great diversity which includes liverworts, Mosses and Hornworts. Bryophyte in general Anthrocopsida includes six genera, all genera are usually placed in Anthocerotaceae. Initially Muller (1941) recognize two family Anthocerotaceae and Notothylaceae with single genus Notothylas Sull. Notothylas forms a connecting link between anthocerotales and hepaticopsida (Proskauer, 1958). Notothylas is reduced form of Anthocerotales on the basis of presence of columella (Pande, 1934). According to revised data (Villarreal et al., 2010) Anthocerotophyta includes fourteen genera; all genera are usually placed in different families. The genus Notothylas is interesting and there are twentythree species known worldwide of these sixteen are accepted name. The genus Anthoceros with ca. nineteen species and genus Nototbylas represented by ca. fifteen species in Indian sub-continent followed by genus Pheoceros with ca. eight species (Singh et al. 2008, Villarreal et al., 2010) India is most diversified geographical area and most of the species from the genera is endemic to the country (Singh, 2002,2008)

The genus Notothylas and Anthoceros is widely distributed in cold and temperate regions of world. There are 58 hornwort taxa has been reported from Indian subcontinent including Srilanka embracing only three families and five genera of hornworts viz. Anthocerotaceae (Anthoceros, Folioceros and Phaeoceros) Notothylaceae (Notothylas), Dedrocerotaceae (Megaceros). Phytogeographical distribution of Notothylas levieri Schiffn. Ex Steph. And Anthoceros punctatus L. in Western Ghats, Eastern \& western

\section{${ }^{*}$ Corresponding Author:}

\section{A.K. Dixit,}

Department of Botany, Guru Ghasidas Vishwavidyalaya, Koni, Bilaspur (Chhattisgarh), 495009.

E-mail: dixitak@live.com
Himalayas, Central India (Pachmarhi) and Uttarakhnad extended to Gangetic planes, whereas Phaeoceros with four taxa is widely known in Western and Eastern Himalayas in India and extended up to very arid regions of Rajasthan was reported by Srivastava 1998. During present investigation of three new species were recorded from Bilaspur ATR and AABR regions, these three identified new records has also revealed some minor variation in their morphological characteristic which may be due to eco-physiological variations in geographical conditions. Achanakmar-Amarkantak area which is declared a natural heritage area of national and international importance and has been declared as Biosphere Reserve by Ministry of Environment and Forest due to its unique ecosystem and status of vegetation in March 2005 (Nath et al.2007). As all these species reportedly growing above $2034 \mathrm{~m}$ altitude and mostly restricted to Himalayan region, despite of average altitude ranging between $332 \mathrm{~m}$ to $902 \mathrm{~m}$ the occurrence of these species in (AABR) and Bilaspur (Chhattisgarh) implication of diversification in hornwort and provides clue to the evolutionary conservation.

\section{Materials and Methods}

The fresh specimen of plant was collected from their natural localities around Bilaspur district of Chhattisgarh. The morphotaxonomical, vegetative and reproductive parts of these taxa were studied. The anatomical structure of thallus, spores and elaters were observed using Leica digital Microscope (DM 2000). The hand sections of thallus were mounted in $30 \%$ aqueous solution of glycerin for observant. The voucher specimens have been deposited in the Department of Botany, Guru Ghasidas Vishwavidyalaya, Bilaspur, and CG. 
Figure 1. Showing area of collection and occurrence of species

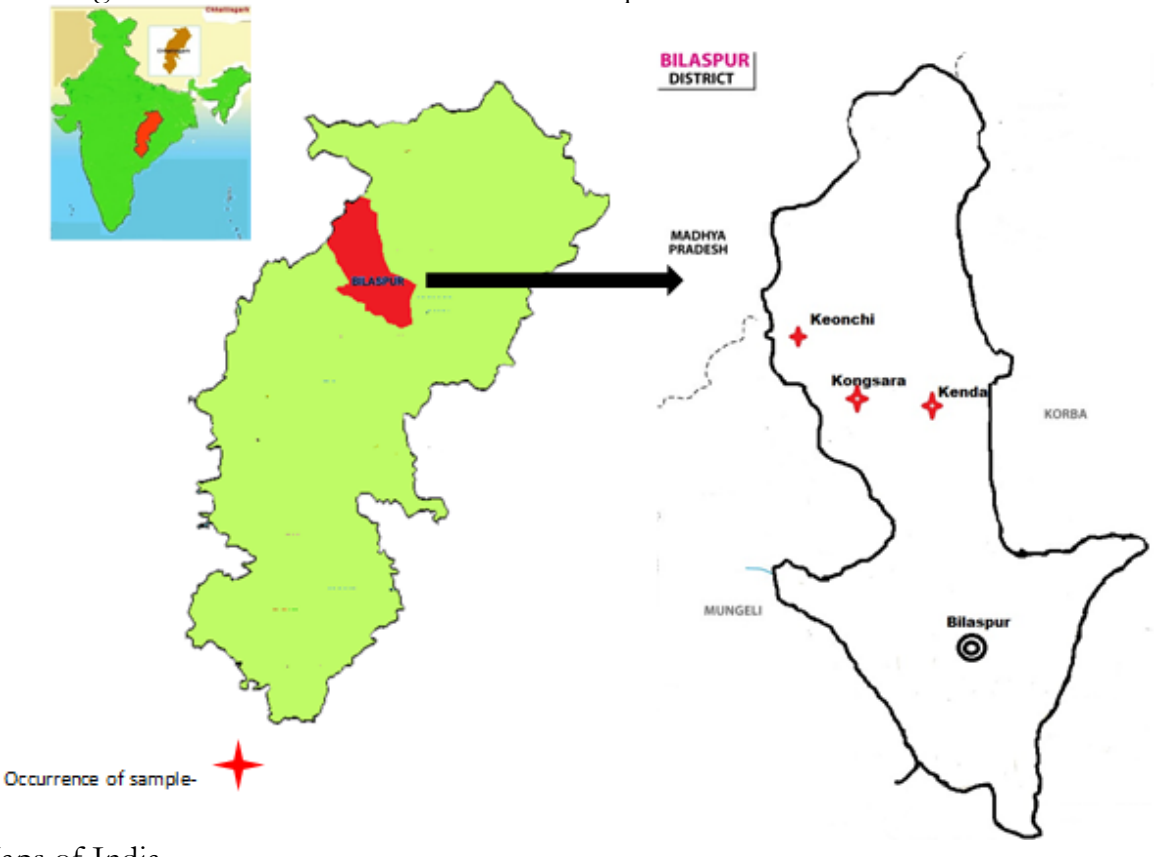

Source: Maps of India
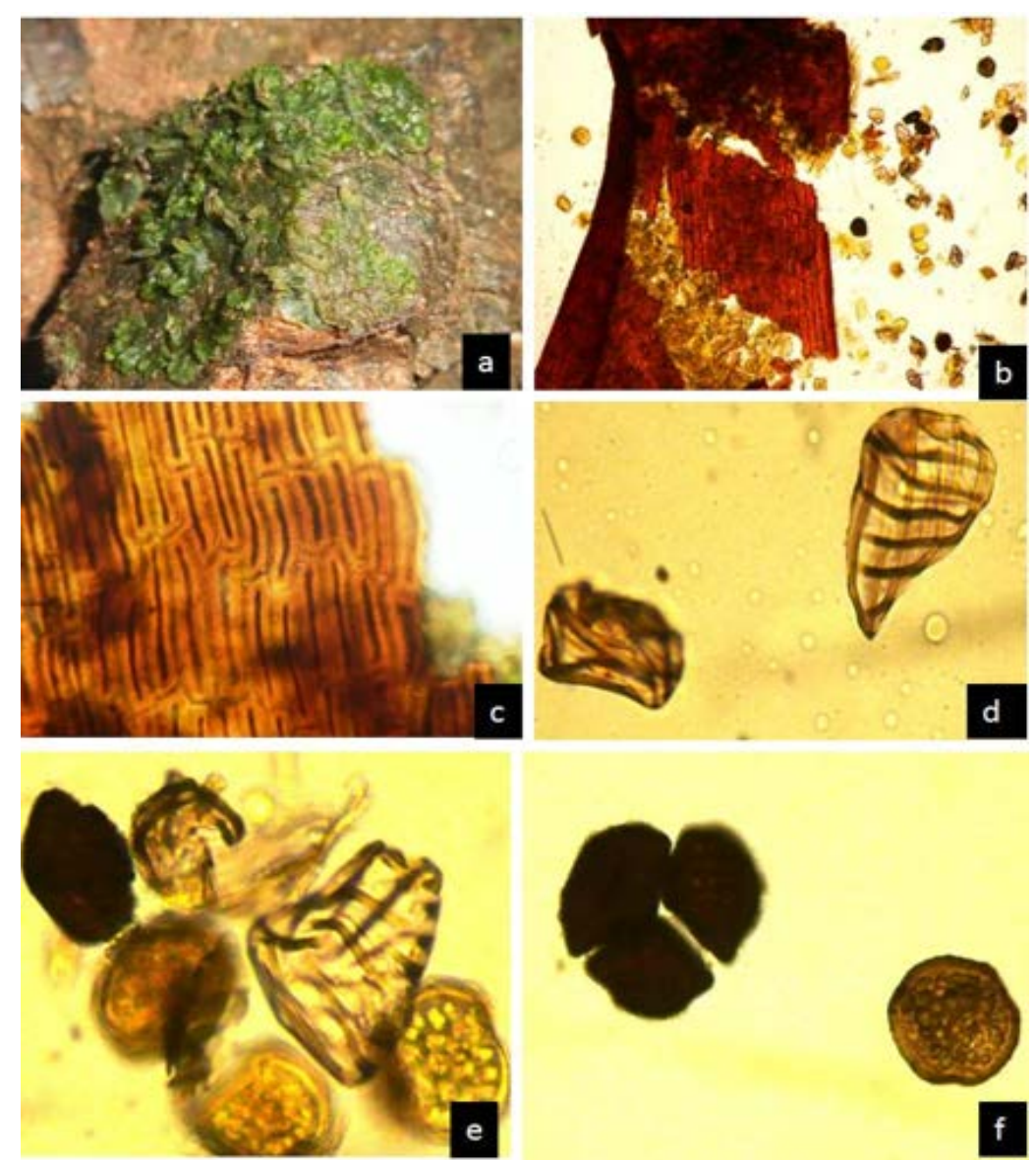

Figure 2. Notothylas levieri Schiffn. Ex Steph., a. Thalii. B-c capsule wall d-f. Spores and pseudo elaters 


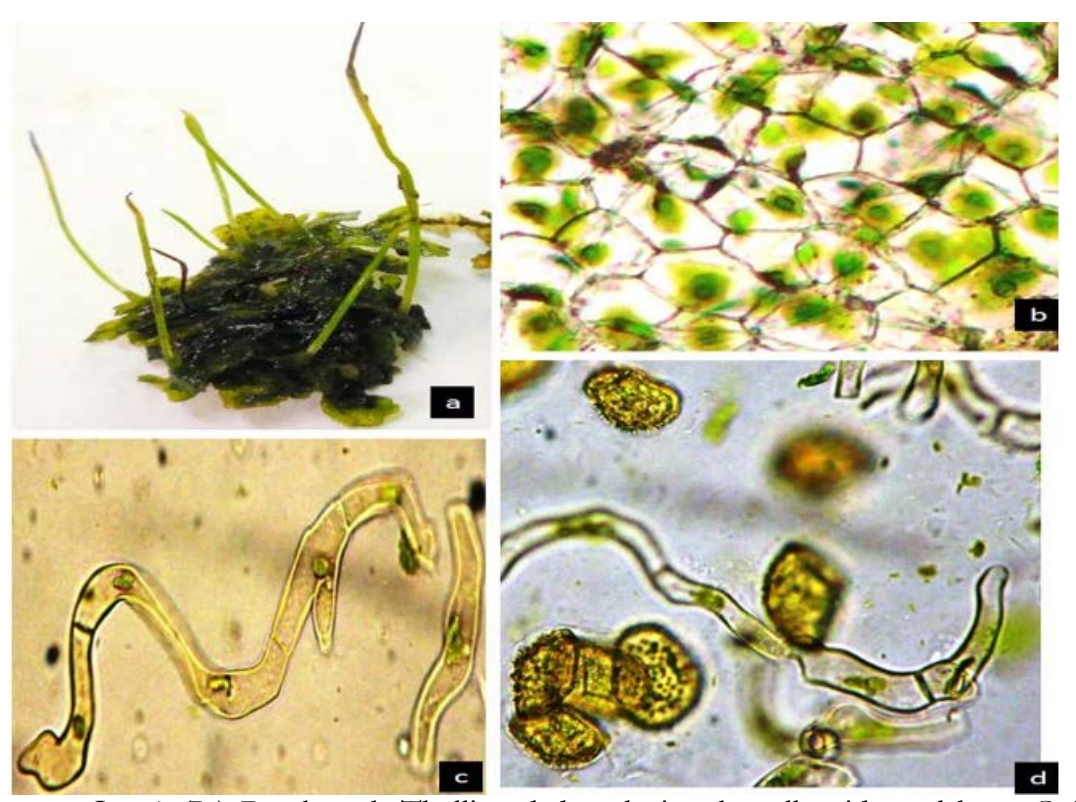

Figure 3. Phaeoceros Leavis (L.) Prosk., a-b Thalli and dorsal view b. cell epidermal layer C-d. Spores and elaters
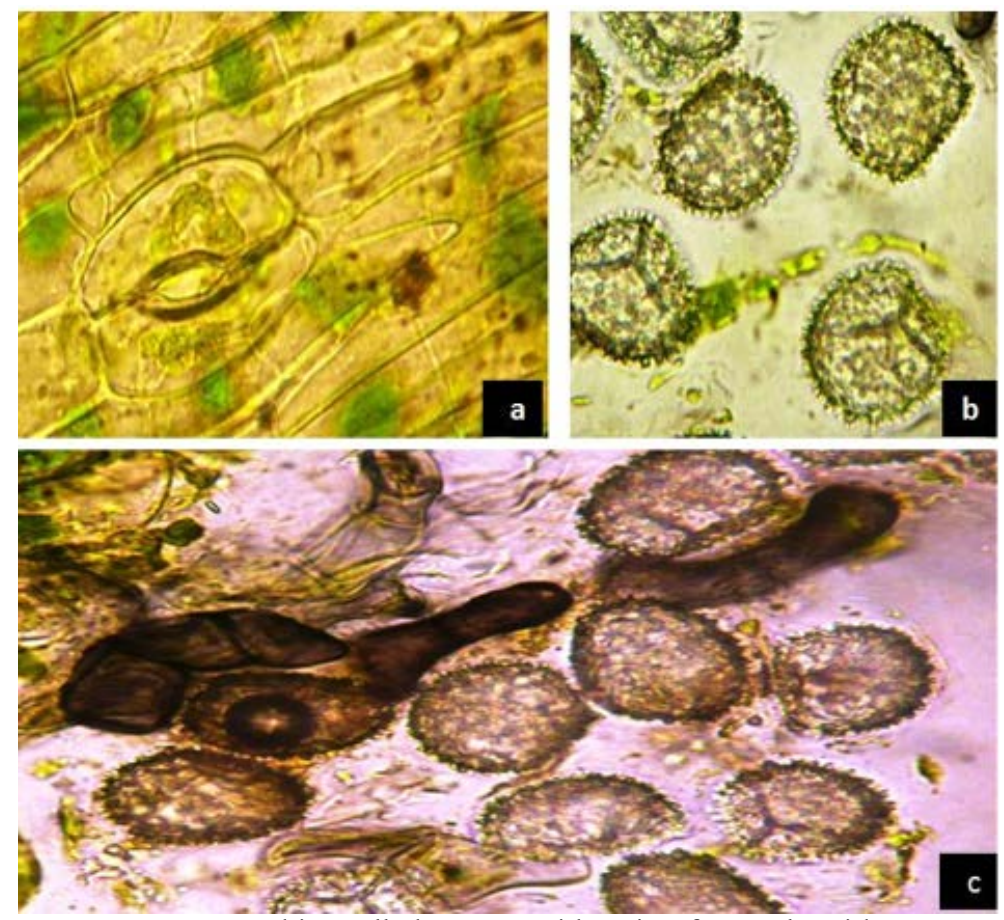

Figure 4. Anthoceros punctatus L. a. thin walled upper epidermis of capsule with stomata b. Spores trilete mark on proximal surface c. Pseudoelaters

\section{Key to species}

1. Cells with 1-4 large chloroplast, capsule linear stunted structure mature sporangia complete ensheathed by a involucres, capsule without dehiscence line or disintegrate when spore released.................. Notothylas 1a

1a. Thallus Monoecious, Presence of columella cells, wall reddish brown, pseudo elaters with helicoids thickenings................. leveri

elaters

short

without lumen

..................... Anthocerotaceae 2a

2a. Spores proximal surface with distinct foveatereticulations with uniformely punctuate ornamentation.... Anthoceros punctatus

3. Thalli without schizogeneous cavities, Pseudoelaters without spiral thiknings.......................Phaeoceros $3 \mathrm{a}$

2. Thalli with numerous schizogeneous cavities, 3a. Proximal surface of the spores with tri radiate jacket cell in 4 tiers, spores brown to black, pseudo

mark, not distinctly bordered by tubercles in form of stripe .......................Phaeoceros leavis 
1. Family - Notothylaceae

Notothylas leveri Schiffr. Ex Steph.

Thallus solid dark green, dorsiventrally flattened, prostrate, monoecious rosette forming in close overlapping masses. Smooth walled rhizoids present at middle of the ventral side. Inner cell uniformly parenchymatous, chlorophyllose, mucilaginous cavity filled with endophytic cyanobacteria. Antheridia in (4-5) groups on dorsal surface, Archegonia on different lobes, sporangia marginal, cylindrical, pointed, non-collumellate, capsule wall orbicular or suborbicular outlined, 1-2 cell thin toward margin and 4-5 cell thickness in middle surrounded the central mass of spores. Spores and elaters dispersed in the centre with oblique with thin bands. Spores are globose, dark brown to opaque. The presence of eight rows of special cells along with margin of each row in sporogonium is characteristic of the species, the epidermal cells are dark brown in colour which is distinguished easily by rest of cells. They are devoid of columella cells. Pseudoelaters dark blackishbrown $(50 \mu \mathrm{m})$ helicoids incomplete spiral bands.

Specimen examined-

ACH/BRY/ANT/0365025/GGV/BOT/MAK BHT/BRY/ANT/0365021/GGV/BOT/MAK; 23-10-2014, GPS location, Bhanwartonk-latitude$22^{\circ} 36^{\prime \prime} 33.52^{\prime}$ longitude - 810 54"44.16' altitude $453.2 \mathrm{~m}$. Chaiturgarh -latitude- $22^{\circ} \quad 30^{\prime \prime} 42.186^{\prime}$ longitude - $82^{\circ} 16^{\prime \prime} 15.108^{\prime}$ altitude - 359.8m Keonchi -latitude- $22^{0} 24^{\prime \prime} 17.885^{\prime}$ longitude - $81^{\circ}$ 52"7.8900' altitude $-433.2 \mathrm{~m}$. Habitat - wet soil surface, terricolous.

\section{Distribution}

Eastern Himalaya (Sikkim, Meghalaya, Assam), Western Himalaya (Dehradoon, Massoorie), Western ghats (Maharastra, Kerala) Central India (Panchmari)

Chhattisgarh-Bhanwartonk, Kenda (Bilaspur), Keonchi (Achankmar Amarkantak Biosphere reserve), Chaiturgarh (Pali, Korba)

2. Family- Anthocerotaceae (Gray) Trevision em. Bharad.

Phaeoceros leavis (L.) Prosk., in Bull.Torrey Bot.Club 78: 347.1951.

Plants monoecious, thalli lobed with wavy margin, usally broad at apex and narrowing towards base, spongy with mucilage chambers; sporophyte erect, stomataiferous, with 2 reiniform guard cells of the epidermal layer of capsule. Spores yellowish green 33-36 $\mu \mathrm{m}$ in diameter, sporoderm minutely papillate- granulose triradiate mark proximal faces indistinct with rounded depressions in center. Pseudoelaters slight greenish yellow (156-257 $\mu \mathrm{m})$ long, thin walled slender 1-4 cell often branched Specimen examined SHV/BRY/ANT/367007/GGV/BOT/MAK; CHT/BRY/ANT/367007/GGV/BOT/MAK 2310-2014, 14-11-2015, GPS location, Chaiturgarh - latitude- $22^{\circ} 30^{\prime \prime} 42.186^{\prime}$ longitude - $82^{\circ} \quad 16^{\prime \prime} 15.108^{\prime}$ altitude $-359.8 \mathrm{~m}$. Shivtarai-latitude- $22^{\circ} 24^{\prime \prime} 17.885^{\prime}$ longitude - $81^{\circ} 52^{\prime \prime} 7.8900^{\prime}$ altitude $-433.2 \mathrm{~m}$.

Distribution

Weastern Himalaya (Shimla, Pauri, Massoorie), Eastern Himalaya (Ukhrul, Nathula road, Mongpo, Darjeeling, Cherrapunji, Gangtok), South India (Ooty, Mukurty, Kodaikanal, Devikanal, Mysore), Rajsthan and Gujrat.

Chhattisgarh- Shivtarai (Achankmar Amarkantak biosphere reserve), Chaiturgarh (Pali, Korba)

3. Family-Anthocerotaceae (Gray) Trevision em. Bharad.

Anthoceros punctatus L. Sp. P1 2: 1139.1753.

Thalli medium size, in rosettes, ecostate, thallus tapering, upto $6 \mathrm{~mm}$ long,

Nostoc colonies uncommon, scattered across the ventral side of thallus. Anthredia not seen capsule frequent upto $3 \mathrm{~cm}$ long bivalved, with well develop columella. Epidermal cell capsule walls rectangular to narrow rectangular, thick- walled and stomata scattered, each stoma with two reniform guard cells surrounded by 5-7 cells; cells of inner lining layer capsule walls rectangular, sometimes with irregular dark thin bands on tangential walls. Spores greenish - brown to black, forming reticuloid- semireticulate patteren, proximal face with a prominent trilet mark foveate reticulation not spiny, distal face with spinulate reticulation sometimes bifurcate apically. Pseudoelaters blackish brown usually 2-4 cell cells sometimes stout $(95-180 \mu \mathrm{m})$ long. Cells narrowly rectangular mostly thikwall without regular spiral thickening.

Specimen examined-

ACH/BRY/ANT/0365022/GGV/BOT/MAK,

GPS location, latitude- $22^{\circ} 24^{\prime \prime} 17.885^{\prime}$ longitude -

$81^{0} 52^{\prime \prime} 7.8900^{\prime}$ altitude $-433.2 \mathrm{~m}$.

Habitat -wet soil surface, terricolous.

Distribution-

Weastern Himalaya (Massoorie Nainital), Eastern Himalaya, Shilong, Manipur, Gauhati Central India (Mt. Abu, Gorakhpur, Bhopal)

Western ghats, Karnataka.

Chhattisgarh- Keonchi, (Achankmar Amarkantak Biosphere reserve).

\section{Result}

During the present investigation on bryophytes of Bilaspur and Achanakmar-Amarkantak Biosphere reserve three species one from Family Notothylaceace Notothylas levieri Schiffn. Ex Steph. Two from Anthocerotaceae Phaeceros leavis (L) Prosk., Anthoceros punctatus L. has been identified.

\section{Discussion}

Present investigation is a first attempt in filling a little of the serious gaps in knowledge about hornwort flora of Chhattisgarh, India. Notothylas levieri Schiffn. Ex Steph., Phaeoceros leavis (L.) Prosk. 
and Anthoceros punctatus L. is reported from Chhattisgarh state of India for the first time. Present study suggests that it may overlook the Bryophyte diversity, and needs fresh inventory in this area. There is a need to strengthen and updating database of Bryophyte status, which will guide in the development of new conservation strategies for the region and AABR

\section{Acknowledgements}

The authors are thankful to The UGC National fellowship for the financial assistance. The authors are also grateful to the CCFO, (AABR) Bilaspur forest division.

\section{References}

1. Asthana, A.K. and Srivastava, S.C. "Indian Hornwort (A Taxonomic study)" Bryophtorum bibliotheca. 42(1991):1-58.

2. Asthana, A.K. and Nath, V. "Observations on the rare Indian hornwort Anthoceros alpinus Steph". Journal of Bryology 26 (2004):303-305.

3. Chatanaorrapint, S. "Notothylas irregularlis (Notothyladeace) Anthocerotophyta a new species of horn wort from Northen thiland" Acta botanica Hungarica 56 (2014):269-274

4. Kashyap, S.R. "Liverworts of the western Himalayas and the Punjab plains part I" Research Co. publication Delhi(1929-32) 35-38

5. Madhusoodan, P.V. and Manju, C. Nair "Ricciocarpus Natans (L.) Corda (Ricciaceae) and Notothylas Liveiri schiffin. Ex. steph. (Notothylaceae) two new bryophyte record form south India" Indian journal of Forestry vol.26(3) (2003): 295-298

6. Muller, K., Beitrage Zur. "Systematik der Lebermoose-II" Hedwigia 80(1941):90-118.

7. Nath, V., Ashtana. A.K., and Kapoor, R. "Enumeration of the Mosses in Amarkantak (Madhya Pradesh), India-I." Taiwania, 52 (2) (2007):168-176.

8. Pande, S.K. On the Morphology of Notothylas levieri Schiff. M.S. Proc. Indian Acad.Sci 1(1934);205217
9. Peng, T. and Zhu, R. "A revision of genus Anthoceros (Anthocerotaceae, Anthocerotophyta) in China." Phytotaxa 100(1) (2013): 21-35.

10. Peng, T. and Zhu, R. "A revision of genus Notothylas (Notothylodoceae Anthocerophyta) in china." Phytotaxa 156(2014):156-164

11. Proskauer, J. "Nachtrag zur Familie Anthocerotaceae. In K. Müller (Ed.) Die Lebermoose Europas, Rabenhorst's Keyptogamen- Flora 3rd edn., (1958) 1303-1319

12. Renzaglia, K.S. "A comparative morphology and developmental anatomy of the Anthocerotophyta." Jour. Hattori Bot.Lab. 44(1978): 30-90

13. Srivastava, S.C. "Distribution of Hepaticae and Anthocerotae in India. In Copra RN, (ed.), Topics in Bryology." Allied publishers Ltd, (1998) 53-88 New delhi

14. Singh, D.K. "Notothylaceae of India and Nepal (A Morphotaxonomic revision)." Bishen-singh Mahendra Pal singh, (2002) India.

15. Singh, D.K. "Red- listing of Hepaticae and Anthocerotae in India in": Mohamed, H., Baki B.B., Boyce, A.N. and Lee, P.K.Y. (eds.) Bryology in new Millennium, (2008) 451-458 University of Malaya Kualalumpur.

16. Singh, D.K. and Singh, S.K., "Scanning electron Microscopic Studies on Sporoderm of some Indian Liverworts and Hornworts." In Mohamed H. et al (eds.), Bryology in the New-millennium University of Malaya. (2008) 291-317 Kualulumpur.

17. Udar, R. and Chandra, V. "A new species of Notoylas Sull., N. Pandei udar ET. Chandra from India" Geophytology. 7(2) (1977): 142-146.

18. Villarreal, J.C., Christine, D.C., Hagborg, A., Soderstrom, L. and Renzaglia, S.K. "A Synthesis of Hornworts Diversity pattern causes and future work." Phytotaxa 9(2010): 150-166 Mangolia press.

\section{Cite this article as:}

Mery Aradhna Kerketta and A.K. Dixit. Enumeration of the New Hornworts from Bilaspur (Chhattisgarh), India. Annals of Plant Sciences 6.11 (2017) pp. 1758-1762. doi: http://dx.doi.org/10.21746/aps.2017.6.11.7 